University of Nebraska - Lincoln

DigitalCommons@University of Nebraska - Lincoln

U.S. Environmental Protection Agency Papers

U.S. Environmental Protection Agency

2007

\title{
Florida seagrass habitat evaluation: A comparative survey for chemical quality
}

Michael A. Lewis

U.S. Environmental Protection Agency

Darrin D. Dantin

U.S. Environmental Protection Agency

Cynthia A. Chancy

U.S. Environmental Protection Agency

Kathryn Abel

Department of Biological Sciences, University of West Florida, Pensacola, FL 32514, USA

Christopher G. Lewis

Department of Water and Soil Science, University of Florida, Gainesville, FL 32103, USA

Follow this and additional works at: https://digitalcommons.unl.edu/usepapapers

Part of the Civil and Environmental Engineering Commons

Lewis, Michael A.; Dantin, Darrin D.; Chancy, Cynthia A.; Abel, Kathryn; and Lewis, Christopher G., "Florida seagrass habitat evaluation: A comparative survey for chemical quality" (2007). U.S. Environmental Protection Agency Papers. 19.

https://digitalcommons.unl.edu/usepapapers/19

This Article is brought to you for free and open access by the U.S. Environmental Protection Agency at DigitalCommons@University of Nebraska - Lincoln. It has been accepted for inclusion in U.S. Environmental Protection Agency Papers by an authorized administrator of DigitalCommons@University of Nebraska - Lincoln. 


\title{
Florida seagrass habitat evaluation: A comparative survey for chemical quality
}

\author{
Michael A. Lewis ${ }^{\text {a,* }}$, Darrin D. Dantin ${ }^{a}$, Cynthia A. Chancy ${ }^{a}$, \\ Kathryn C. Abel ${ }^{\mathrm{b}}$, Christopher G. Lewis ${ }^{\mathrm{c}}$ \\ ${ }^{a}$ U.S. Environmental Protection Agency, Office of Research and Development, National Health \& Environmental Effects Research Laboratory, \\ Gulf Ecology Division, 1 Sabine Island Drive, Gulf Breeze, FL 32561, USA \\ ${ }^{\mathrm{b}}$ Department of Biological Sciences, University of West Florida, Pensacola, FL 32514, USA \\ ${ }^{c}$ Department of Water and Soil Science, University of Florida, Gainesville, FL 32103, USA
}

Received 25 October 2005; received in revised form 3 April 2006; accepted 25 April 2006

Some anthropogenic contaminants were prevalent in seagrass and their rooted sediments but the biological significance is unknown.

\begin{abstract}
Contaminant concentrations were determined for media associated with 13 Florida seagrass beds. Concentrations of 10 trace metals were more commonly detected in surface water, sediment and two seagrass species than PAHs, pesticides and PCBs. Concentrations of copper and arsenic in surface water exceeded Florida aquatic life criteria more frequently than other trace elements. Total organic carbon, mercury, chromium, zinc, total chlordane, total PAHs, total PCBs, DDD and DDE were significantly greater in seagrass-rooted sediments than adjacent non-vegetated sediments. Total DDT, DDD, DDE, total chlordane, arsenic, copper and nickel exceeded proposed sediment quality guidelines at six of 13 grass beds. Pesticides, PAHs, and PCBs were below detection in seagrass tissues. Mercury, cadmium, nickel, lead and silver were detected in $50 \%$ or more of the tissues for Thalassia testudinum (turtle grass) and Halodule wrightii (shoal grass). Spatial, interspecific and tissue differences were usually an order of magnitude or less.
\end{abstract}

(C) 2006 Elsevier Ltd. All rights reserved.

Keywords: Seagrass; Sediment; Water; Trace metals; Organic chemicals; Florida

\section{Introduction}

Anthropogenic contaminants enter the Gulf of Mexico from a variety of point and non-point sources. For example, approximately, 5850 metric tons (13 million pounds) of toxic substances were discharged from wastewater outfalls and about 4500 metric tons (10 million pounds) of pesticides were applied to agricultural fields in Gulf of Mexico coastal counties during 1987 (Pait et al., 1992). Herbicide use in the Gulf of Mexico region is the highest for any coastal area in the U.S.

\footnotetext{
* Corresponding author. Tel./fax: +1 8509349382.

E-mail address: lewis.michael@epa.gov (M.A. Lewis).
}

(Pait et al., 1992). In addition, potentially toxic trace elements such as copper, zinc and chromium are included in the top 10 toxicants released to estuarine areas in this region (U.S. EPA, 1994). Despite numerous contaminant sources, the fate and effects of most potential toxicants are not known for most indigenous flora and fauna including species at risk such as seagrasses.

Factors controlling seagrass distribution and condition are of increasing interest to the scientific community due to their ecological and economic value (Duarte, 1999). Seagrass communities have at least 13 ecological roles (Dawes et al., 2004). Seagrasses support important grazing and detrital food webs, stabilize sediment, and are important in global carbon and nutrient cycling. Furthermore, hundreds of planktonic, 
epibenthic and infaunal species are dependent upon grass beds for survival (Virnstein, 1987; Jackson et al., 2001). For example, $70-90 \%$ of commercial fish rely on seagrass habitat for a part of their life cycle. The value of one seagrass acre has been estimated to be between 9000 and 28,000 USD (USGS, in press).

Six of eleven seagrass species found in the U.S. near-shore waters are common in the Gulf of Mexico coastal region. Seagrass coverage in the northern Gulf of Mexico has been estimated to be 2.5 million acres (about 1 million ha) (U.S. EPA, 1992) and 2.1 million acres (850 thousand acres) for Florida's Gulf coast (Dawes et al., 2004). Seagrasses in this region have declined $20-100 \%$ in some areas during the past 50 years (USGS, in press). For example, approximately $85 \%$ of the seagrass acreage in Florida has been lost (U.S. EPA, $1990,1992)$. In a broader context, seagrass ecosystems containing 24 species have been reduced at 40 worldwide locations (Hemminga and Duarte, 2000). These reductions have been attributed to natural causes such as grazing, changes in temperature and salinity, sedimentation, erosion and disease and to anthropogenic factors such as prop scarring, dredging, eutrophication, siltation and toxic chemicals (Hemminga and Duarte, 2000). The contribution of toxic chemicals to seagrass declines, the focus of this study, is largely unknown and has been investigated less frequently than the effects attributable to nutrient enrichment which is considered the primary cause of seagrass declines. However, some consider the impact of anthropogenic chemicals to be significant and worthy of increased investigation (Catsiki and Panayotidis, 1993; Short and Wyllie-Echeverria, 1996; Peters et al., 1997; SchlacherHoenlinger and Schlacher, 1998; Bester, 2000; Ralph, 2000).

Understanding the fate and effects of non-nutrient anthropogenic chemicals has not been a priority research topic for Florida seagrass beds despite the importance of the information to the risk assessment process. Studies have been conducted more commonly to determine seagrass distribution (Iverson and Bittaker, 1986; Hall et al., 1999; Zieman et al., 1999; Fourqurean et al., 2002), biomass and productivity (Dawes et al., 1985; Tomasko and Hall, 1999; Bologna and Haywick, 2002), environmental controlling factors (Livingston et al., 1998; Fletcher and Fletcher, 1995; Erskine and Koch, 2000; Koch and Erskine, 2001; Irlandi et al., 2002), and the diversity of seagrass-dependent flora and fauna (Hall and Bell, 1993; Frankovich and Zieman, 1994; Matheson et al., 1999).

Due to the scarcity of reported information, a screening survey was conducted to determine the magnitude of contaminant concentrations in seagrass tissues, vegetated and non-vegetated sediments and overlying surface waters collected from 13 Florida grass beds. This paper summarizes the results of the survey and compares them to those previously reported for other grass beds and geographical areas. The results serve as a baseline database to which future evaluations can be compared, represent realistic exposure concentrations which will be useful for future phytotoxicity tests, and add to the ongoing evaluation of the suitability of seagrasses to serve as indicators of environmental condition (Brix et al., 1983; Ward et al.,
1986; Tiller et al., 1989; Catsiki and Panayotidis, 1993; Pergent-Martini, 1998; Prange and Dennison, 2000).

\section{Material and methods}

\subsection{Study areas}

Surface water, sediment and seagrass were collected once from 13 Florida seagrass beds at seven locations during 2001-2002 (Fig. 1). Six beds were sampled in Santa Rosa Sound (Santa Rosa County, FL) adjacent to a golf complex, residential canal, residential bayou, public marina, municipal wastewater outfall (Pensacola Beach) and the Gulf Islands National Seashore. Santa Rosa Sound adjacent to the National Seashore is a Florida Outstanding Water designated to receive the highest level of protection. In addition, seagrasses were collected from St. Joseph Bay (Bay County, FL) adjacent to a public marina and residential bayou and from channels associated with Ohio and Little Duck Keys (Monroe County, FL).

\subsection{Media collection}

Sediments attached to roots and rhizomes were collected by hand. Sediments were collected also from adjacent non-vegetated areas to a depth of approximately $13 \mathrm{~cm}$ using a petite ponar grab. Sediments from the top $5 \mathrm{~cm}$ were passed through a sieve (10-mm-mesh size) to remove any vegetative material and benthic organisms prior to homogenization and storage at $4{ }^{\circ} \mathrm{C}$ in acid-washed glass containers. One grab sample of surface water was collected above each seagrass bed at an approximate depth of $0.2 \mathrm{~m}$ and stored in acidwashed bottles at $4{ }^{\circ} \mathrm{C}$ until chemical analysis. Samples for trace metal analyses were preserved with $1 \%$ concentrated $\mathrm{HCl}$.

Whole plant Thalassia testudinum Banks ex König (turtle grass) and $\mathrm{Hal}$ odule wrightii Aschers (shoal grass) were collected usually from monotypic stands at a depth of $1.5 \mathrm{~m}$ or less using a spade shovel. T. testudinum is considered an index or keystone species (Peters et al., 1997) and it and $\mathrm{H}$. wrightii are common to the northwest and southern coasts of Florida (Iverson and Bittaker, 1986). After uprooting and removal of sediments, the plants were thoroughly rinsed at least twice on site with seawater to remove remaining inorganic particles. Whole plants were placed in sealed polyethylene bags, stored on ice and returned to the lab. Epibiota were removed from leaves by scraping with razor blades. Whole green blades (non-calcareous) and rhizomes and roots were removed and rinsed with deionized water and stored separately at $4{ }^{\circ} \mathrm{C}$ before chemical analysis.

\subsection{Chemical analyses: surface waters}

Surface waters, sediments and seagrass tissues collected from each site were analyzed once for 10 trace metals, 23 polycyclic aromatic hydrocarbon compounds (PAH), 25 chlorinated pesticides and 18 polychlorinated biphenyl congeners (PCB). All chemicals in surface water and other media were analyzed following U.S. EPA (1997) procedures. Trace metals were analyzed with a Jarrell-Ash Atomcomp Series 800 inductive coupled plasma mass spectrometer (Fisher Scientific Co., Franklin, MA). Mercury was quantified with a Leeman PS 200 Automated Mercury Analyzer (Leeman Labs Inc., Hudson, $\mathrm{NH})$ using cold vapor spectrometry with tin (IV) as the reductant. Concentrations of PAHs, chlorinated pesticides, and PCBs were determined using an HP 5890 Series II gas chromatograph (Hewlett-Packard Corp., Palo Alto, CA). The detection limits $(\mu \mathrm{g} / \mathrm{L})$ were between 0.2 and 5.0 (trace metals), 19.0 (PCBs and chlorinated pesticides) and 4.0 (PAHs). Contaminant concentrations in surface water were compared to Florida water quality criteria for protection of marine life (Florida Department of Environmental Protection, 1996).

\subsection{Chemical analysis: sediments}

Vegetated and adjacent non-vegetated sediments were analyzed for total organic carbon (method detection limit $=0.03 \%$ ) and particle size distribution using standard procedures (APHA et al., 1995). Sediments were analyzed for trace metals following U.S. EPA techniques (U.S. EPA, 1997) for concentrated nitric 


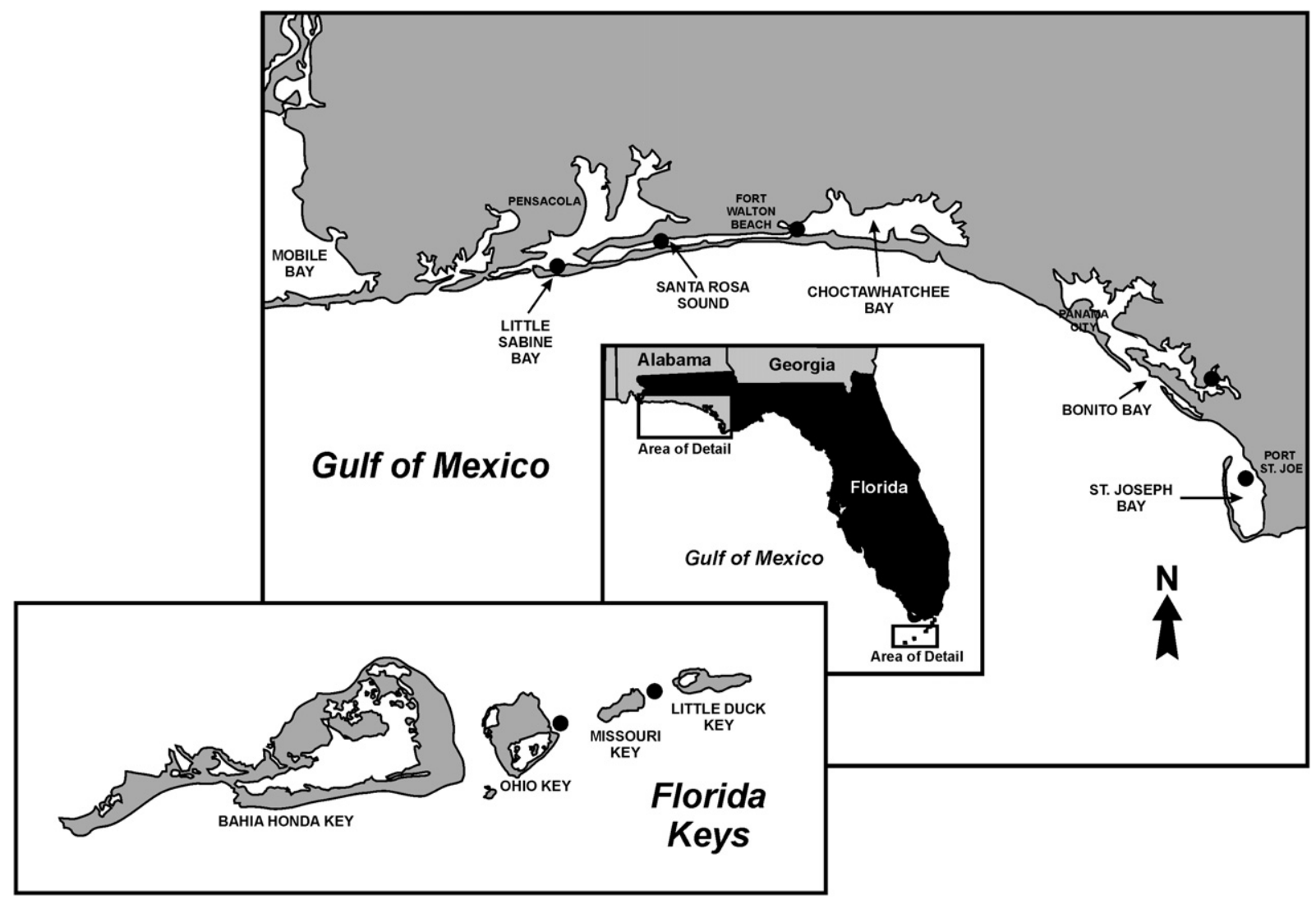

Fig. 1. Seven locations

) in northwest and south Florida where 13 seagrass beds were sampled for surface water, sediment and whole plants.

acid extraction, clean-up and analysis using the same instrumentation as for surface water. Method detection limits were between 0.004 and 0.4 ( $\mu \mathrm{g} / \mathrm{g}$ dry wt.). Method detection limits for some trace metals and media (sediment, seagrass tissue) differed on occasion due to use of two analytical support laboratories.
Sediments were solvent extracted (acetone/acetonitrile) for $30 \mathrm{~min}$ and then analyzed for PAHs, chlorinated pesticides, and PCBs using an HP-5890 Series II Gas Chromatograph (Hewlett-Packard, Palo Alto, CA) equipped with an HP-5 fused silica analytical column and mass spectrum temperature

Table 1

Trace metal concentrations $(\mu \mathrm{g} / \mathrm{L})$ in surface water over seagrass beds

\begin{tabular}{|c|c|c|c|c|c|c|c|}
\hline \multirow[t]{2}{*}{ Locations } & \multicolumn{7}{|c|}{ Trace metals } \\
\hline & As & $\mathrm{Cr}$ & $\mathrm{Cu}$ & $\mathrm{Ni}$ & $\mathrm{Pb}$ & $\mathrm{Zn}$ & Total $\mathrm{Hg}$ \\
\hline \multicolumn{8}{|l|}{ Santa Rosa Sound } \\
\hline • Bayou (B) & 75.6 & $<0.8$ & 58.5 & $<0.9$ & $<0.6$ & $<3.0$ & $<0.2$ \\
\hline - Golf Complex (GC) & 64.0 & $<0.8$ & 56.5 & $<0.9$ & $<0.6$ & $<3.0$ & $<0.2$ \\
\hline - Canal (C) & 70.4 & $<0.8$ & 61.1 & $<0.9$ & $<0.6$ & 19.0 & $<0.2$ \\
\hline - National Seashore (NS) & 70.6 & $<0.8$ & 55.9 & $<0.9$ & $<0.6$ & $<3.0$ & $<0.2$ \\
\hline - Wastewater Outfall (WO) & 70.7 & $<0.8$ & 58.1 & $<0.9$ & 5.3 & 27.6 & 0.38 \\
\hline - Marina (M) & 55.7 & $<0.8$ & 57.6 & 20.6 & 16.7 & 66.4 & 0.31 \\
\hline Little Sabine Bay (LSB) & 56.3 & $<0.8$ & 56.4 & $<0.9$ & 11.2 & 32.6 & $<0.2$ \\
\hline Choctawhatchee Bay (CB) & 67.5 & 5.2 & 14.3 & 5.8 & 1.5 & $<3.0$ & $<0.2$ \\
\hline Bonito Bay (BB) & 47.4 & $<0.8$ & 26.2 & $<0.9$ & $<0.6$ & $<3.0$ & 0.24 \\
\hline St. Joseph Bay ${ }^{\mathrm{a}}$ & 36.3 & 3.1 & 13.9 & 5.2 & 1.3 & $<3.0$ & $<0.2$ \\
\hline Ohio Key (OK) & 42.4 & 25.4 & 16.8 & 6.0 & $<0.6$ & $<3.0$ & $<0.2$ \\
\hline Little Duck Key (LDK) & 44.3 & 4.7 & 17.7 & 6.3 & 0.7 & $<3.0$ & $<0.2$ \\
\hline $\operatorname{MDL}(\mu \mathrm{g} / \mathrm{L})^{\mathrm{b}}$ & 5.0 & 0.8 & 0.7 & 0.9 & 0.6 & 3.0 & 0.2 \\
\hline$>\mathrm{MDL}^{\mathrm{c}}$ & 100 & 33 & 100 & 50 & 50 & 33 & 25 \\
\hline WQC $^{\mathrm{d}}$ & $<50$ & $<50$ & $<2.9$ & $<8.3$ & $<5.6$ & $<86$ & $<0.25$ \\
\hline
\end{tabular}

Values are for one sample. Concentrations of cadmium, silver and selenium were below the method detection limits of $1.0 \mu \mathrm{g} / \mathrm{L}$ (cadmium and silver) and 5.0 $\mu \mathrm{g} / \mathrm{L}$ (selenium). Concentrations in bold exceed water quality criteria for Florida marine waters (Florida Department of Environmental Protection, 1996).

${ }^{\text {a }}$ For both marina $(\mathrm{SJBM})$ and bayou sites (SJBB).

b MDL - method detection limit.

${ }^{c}$ Percent of samples exceeding MDL.

${ }^{\mathrm{d}}$ Water quality criteria $(\mu \mathrm{g} / \mathrm{L})$. 
Table 2

Total organic carbon (\%) and particle size distribution (\%) for sediments collected from seagrass vegetated (V) and adjacent non-vegetated (NV) areas

\begin{tabular}{|c|c|c|c|c|c|c|c|c|}
\hline \multirow[t]{3}{*}{ Locations } & \multirow{2}{*}{\multicolumn{2}{|c|}{ Total organic carbon }} & \multicolumn{6}{|c|}{ Particle size distribution } \\
\hline & & & \multicolumn{2}{|c|}{ Sand } & \multicolumn{2}{|c|}{ Silt } & \multicolumn{2}{|c|}{ Clay } \\
\hline & $\mathrm{V}$ & $\mathrm{NV}$ & V & $\mathrm{NV}$ & V & NV & $\mathrm{V}$ & $\mathrm{NV}$ \\
\hline \multicolumn{9}{|l|}{ Santa Rosa Sound } \\
\hline - Bayou & 0.9 & 0.1 & 93 & 99 & 3 & 0 & 4 & 1 \\
\hline - Golf Complex & 1.1 & 0.3 & 93 & 98 & 3 & $<1$ & 4 & 1 \\
\hline - Canal & 0.2 & 0.1 & 98 & 99 & 0 & $<1$ & 2 & $<1$ \\
\hline - National Seashore & 0.5 & 0.1 & 96 & 99 & 1 & 1 & 2 & 1 \\
\hline - Wastewater Outfall & 0.2 & 0.1 & 99 & 99 & 0 & $<1$ & 1 & $<1$ \\
\hline - Marina & 0.3 & $<0.1$ & 95 & 98 & 2 & 2 & 3 & $<1$ \\
\hline Little Sabine Bay & 0.4 & 0.1 & 96 & 99 & 2 & $<1$ & 2 & $<1$ \\
\hline Choctawhatchee Bay & 1.8 & 1.7 & 97 & 97 & 1 & 1 & 2 & 1 \\
\hline Bonito Bay & 0.4 & 0.1 & 97 & 99 & 1 & 0 & 3 & 1 \\
\hline \multicolumn{9}{|l|}{ St. Joseph Bay } \\
\hline - Marina & 1.0 & 0.6 & 97 & 97 & 1 & 1 & 2 & 2 \\
\hline - Residential Bayou & 12.0 & 0.7 & 91 & 97 & 6 & 1 & 3 & 2 \\
\hline Ohio Key & 0.2 & 0.2 & 86 & 87 & 11 & 6 & 3 & 7 \\
\hline Little Duck Key & 1.0 & 0.8 & 87 & 65 & 11 & 27 & 2 & 8 \\
\hline
\end{tabular}

Concentrations are for one sample.

detector. The method detection limits (ng/g dry wt.) were 1.0 (PAHs) and 0.2 (PCB congeners and chlorinated pesticides).

Sediment contaminant concentrations in sediment were compared to sediment quality assessment guidelines (SQG) proposed for Florida coastal areas (Florida Department of Environmental Protection, 1994; MacDonald et al., 1996). The threshold effects level (TEL) and probable effects level (PEL) guidelines were used in the comparisons (U.S. EPA, 1994). The TEL is the threshold effect level above which adverse biological effects may occur to the benthos. Contaminant concentrations exceeding threshold effect level (TEL) guidelines but less than probably effect level (PEL) guidelines are thought to represent minimal risk whereas those exceeding PEL guidelines are more likely to cause negative impacts. For additional perspective, when individual guidelines were not exceeded, the concentrations of individual chemicals detected in each sediment sample were divided by their corresponding TEL and PEL guideline values and the fractions (quotients) summed. This technique has been used elsewhere (Long et al., 1998) and it is based on the assumption of additive chemical toxicity. Summed quotients exceeding one are considered equivalent to the exceedance of at least one SQG.

Normalization of trace metal-to-aluminum ratios was used to determine if the sediment contaminants exceeded geochemical background concentrations. Concentrations of six trace metals were plotted against that for aluminum and then compared to expected ratios for uncontaminated Florida coastal sediments reported by Schropp et al. (1990).

\subsection{Chemical analysis: seagrass}

Methods and instrumentation for extraction, digestion and chemical analysis of seagrass tissues were similar to those used for sediments. Blades and roots and rhizomes (combined) were analyzed separately. Tissue samples were dried overnight at $105{ }^{\circ} \mathrm{C}$ and then digested in 50\% nitric acid using a microwave oven. The method detection limits were between 0.01 and $50.0 \mu \mathrm{g} / \mathrm{g}$ dry wt. (trace metals) and between 2 and $20 \mathrm{ng} / \mathrm{g}$ dry wt. (PAHs, chlorinated pesticides and PCBs).

\subsection{Quality control}

Quality control samples included blanks, sample spikes, sample duplicates, calibration checks and analyses of standard reference materials (SRM $2704-$ Buffalo River sediment; SRM 1547-peach leaves) obtained from the National Institute of Standards and Technology (Gaithersburg, MD). All analytical data met objectives for blanks, control standards, duplicates as well as spike and internal standard recoveries. The average recoveries for trace metals were $80 \%$ (both standard reference materials), $100 \%$ (spiked reagent control sample), and 99\% (spiked sample matrices). Recoveries for pesticide, PAH and PCB matrix-spiked samples averaged $65 \%$ or more.

\subsection{Bioconcentration factors $(B C F)$}

Bioconcentration factors were calculated based on trace metal concentrations in vegetated sediments and above and below substrate tissues as follows:

$\mathrm{BCF}=\frac{\text { Concentration in seagrass tissue }(\mu \mathrm{g} / \mathrm{g} \text { dry wt. })}{\text { Concentration in vegetated sediments }(\mu \mathrm{g} / \mathrm{g} \text { dry wt. })}$

BCF values were also calculated for trace metals in surface water $(\mathrm{mg} / \mathrm{L})$ and epiphyte-free blades ( $\mu \mathrm{g} / \mathrm{g}$ dry wt.). BCF values were not determined for organic contaminants due to infrequent detection.

\subsection{Statistical analysis}

Mean TOC and contaminant concentrations were compared between vegetated and non-vegetated sediments and also between seagrass tissues using one-way analysis of variance (ANOVA) (SAS Institute Inc., 1991). Data were combined from all seagrass beds for these analyses. When $F$ values were significant at $(P<0.05)$, means were compared by use of Tukey's Studentized Range Test.

Table 3

Concentrations (ng/g dry wt.) of total PCBs, PAHs, DDT and chlordane in sediments collected from seagrass vegetated (V) and adjacent non-vegetated (NV) areas

\begin{tabular}{|c|c|c|c|c|c|c|c|c|}
\hline \multirow[t]{2}{*}{ Locations } & \multicolumn{2}{|c|}{ Total PCBs } & \multicolumn{2}{|c|}{ Total PAHs } & \multicolumn{2}{|c|}{ Total DDT } & \multicolumn{2}{|c|}{ Total chlordane } \\
\hline & $\mathrm{V}$ & $\mathrm{NV}$ & $\mathrm{V}$ & $\mathrm{NV}$ & $\mathrm{V}$ & NV & $\mathrm{V}$ & $\mathrm{NV}$ \\
\hline \multicolumn{9}{|l|}{ Santa Rosa Sound } \\
\hline • Bayou & 1.2 & 0.4 & 950.0 & 24.8 & 10.3 & 0.2 & 0.35 & $\mathrm{BD}$ \\
\hline - Golf Complex & 0.9 & 0.4 & 545.0 & 40.5 & 5.0 & 0.6 & 5.0 & $\mathrm{BD}$ \\
\hline - Canal & 0.6 & 0.4 & 35.2 & 3.4 & 0.1 & 0.1 & BD & $\mathrm{BD}$ \\
\hline - National Seashore & 1.1 & 0.3 & 55.9 & 13.3 & 1.4 & 1.6 & 0.10 & BD \\
\hline - Wastewater Outfall & 0.7 & 0.2 & 61.2 & 11.4 & 0.5 & 0.1 & 0.49 & 0.10 \\
\hline - Marina & 1.0 & 0.1 & 122.0 & 13.6 & 0.1 & $\mathrm{BD}$ & $\mathrm{BD}$ & $\mathrm{BD}$ \\
\hline Little Sabine Bay & 1.4 & 0.3 & 181.0 & 10.9 & 0.2 & $\mathrm{BD}$ & 0.10 & $\mathrm{BD}$ \\
\hline Bonito Bay & 7.0 & 0.3 & 204.0 & 31.0 & 1.6 & 0.7 & $\mathrm{BD}$ & $\mathrm{BD}$ \\
\hline $\mathrm{TEL}^{\mathrm{a}}$ & 21.6 & & 1684 & & 3.89 & & 2.26 & \\
\hline $\mathrm{PEL}^{\mathrm{a}}$ & 189 & & 16,770 & & 51.7 & & 4.79 & \\
\hline
\end{tabular}

Concentrations are for one sample and those in bold exceed proposed sediment quality guidelines for Florida near-coastal areas (MacDonald et al., 1996). BD less than method detection limit. Concentrations not available for Choctawhatchee Bay, St. Joseph Bay and Ohio and Little Duck Key channels.

a Threshold (TEL) and probable effect level (PEL) guideline values (ng/g dry wt.). 
Table 4

Trace metal concentrations ( $\mu \mathrm{g} / \mathrm{g}$ dry wt.) in sediment collected from seagrass vegetated $(\mathrm{V})$ and adjacent non-vegetated areas (NV)

\begin{tabular}{|c|c|c|c|c|c|c|c|c|c|c|c|c|c|c|}
\hline \multirow[t]{3}{*}{ Trace metal } & \multicolumn{12}{|c|}{ Santa Rosa Sound } & \multicolumn{2}{|c|}{ Little Sabine Bay } \\
\hline & \multicolumn{2}{|l|}{ Bayou } & \multicolumn{2}{|c|}{ Golf Complex } & \multicolumn{2}{|l|}{ Canal } & \multicolumn{2}{|c|}{ National Seashore } & \multicolumn{2}{|c|}{ Wastewater Outfall } & \multicolumn{2}{|l|}{ Marina } & & \\
\hline & $\mathrm{V}$ & NV & $\mathrm{V}$ & NV & $\mathrm{V}$ & NV & $\mathrm{V}$ & NV & $\mathrm{V}$ & NV & V & NV & V & NV \\
\hline Arsenic & 1.9 & 0.16 & 1.0 & 0.30 & 0.83 & 0.38 & 1.3 & 0.37 & 1.5 & 0.31 & 0.53 & 0.16 & 17.0 & $<1.5$ \\
\hline Cadmium & $<0.2$ & $<0.2$ & $<0.2$ & $<0.2$ & $<0.2$ & $<0.2$ & $<0.2$ & $<0.2$ & $<0.2$ & $<0.2$ & $<0.2$ & $<0.2$ & 0.35 & $<0.2$ \\
\hline Chromium & 6.2 & 0.76 & 5.8 & 2.3 & 1.1 & 0.27 & 4.8 & $<0.20$ & 1.4 & 1.34 & 2.7 & 0.21 & 5.2 & $<0.20$ \\
\hline Copper & 2.7 & 0.25 & 1.5 & 0.44 & 0.82 & $<.08$ & 1.3 & $<.08$ & 0.6 & $<0.08$ & 0.85 & $<0.08$ & 70.8 & 0.25 \\
\hline Mercury & 0.018 & $<0.004$ & 0.005 & $<0.004$ & $<0.004$ & $<0.004$ & 0.007 & $<0.004$ & 0.005 & $<0.004$ & 0.016 & 0.057 & 0.004 & $<0.004$ \\
\hline Nickel & 1.6 & $<0.12$ & 1.2 & 0.14 & 0.51 & $<0.12$ & 1.9 & $<0.12$ & 0.3 & 0.19 & 0.57 & $<0.12$ & 17.3 & $<0.12$ \\
\hline Lead & 2.3 & 0.25 & 1.6 & 0.70 & 0.74 & 0.21 & 1.8 & 0.30 & 1.3 & 0.35 & 1.1 & 0.32 & 28.5 & 0.30 \\
\hline Zinc & 10.0 & 2.5 & 6.5 & 3.5 & 4.1 & 2.3 & 6.8 & 2.4 & 3.0 & 2.5 & 5.0 & 2.2 & 9.4 & 2.8 \\
\hline Selenium & 0.62 & 0.53 & $<0.5$ & 0.87 & $<0.5$ & $<0.5$ & $<0.5$ & $<0.5$ & $<0.5$ & $<0.5$ & 0.62 & $<0.5$ & $<0.5$ & 0.64 \\
\hline Silver & $<0.05$ & $<0.05$ & $<0.05$ & $<0.05$ & $<0.05$ & $<0.05$ & $<0.05$ & $<0.05$ & $<0.05$ & $<0.05$ & $<0.05$ & $<0.05$ & 0.25 & $<0.05$ \\
\hline
\end{tabular}

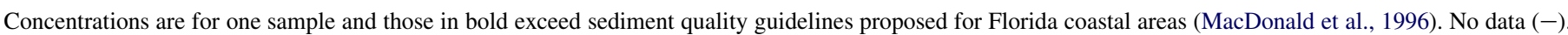

a Threshold (TEL) and probable effect level (PEL) guideline values ( $\mu \mathrm{g} / \mathrm{g}$ dry wt.).

b Guidelines not available.

Data were log-transformed (base 10) when necessary and all assumptions were met for the ANOVA. Method detection limit concentrations (MDL) were used in calculation of means when concentrations were less than the MDL.

\section{Results}

\subsection{Surface water}

Concentrations of all PAH compounds, chlorinated pesticides, PCB congeners, cadmium, selenium and silver were below detection. The seven remaining trace metals were detected in $25-100 \%$ of the total samples analyzed. Of these, total arsenic and copper were detected more commonly (over 813 seagrass beds) and concentrations ( $\mu \mathrm{g} / \mathrm{L})$ ranged from 36.3 to 75.6 (arsenic) and from 13.9 to 61.1 (copper) (Table 1). The environmental fate of mercury is of special concern in the Gulf of Mexico since the entire coastline is under a fish consumption advisory. Total mercury concentrations, ranged from $<0.2$ to $0.38 \mu \mathrm{g} / \mathrm{L}$ and exceeded the water quality criterion of $<0.25 \mu \mathrm{g} / \mathrm{L}$ at two of 13 grass beds. Criterion values were also exceeded for copper and arsenic and, less frequently, for nickel and lead. More trace metals were detected in surface water over grass beds in Santa Rosa Sound near a marina (six), and the fewest (two) were observed in areas adjacent to the golf complex, residential bayou and National Seashore.

\subsection{Sediment}

\subsubsection{Particle size distribution and total organic carbon (TOC)}

Most vegetated and non-vegetated sediments were sanddominated (Table 2). Vegetated sediments contained, on average, $2 \%$ less sand and $1-2 \%$ more silts and clays. Total organic carbon (\%) ranged from 0.2 to 12.0 (vegetated) and from $<0.1$ to 1.7 (non-vegetated). The mean TOC concentration was significantly greater for vegetated sediment.

\subsubsection{Total PAHs, total PCBs and pesticides}

Total concentrations of PCB congeners, PAHs and DDT varied spatially one to two orders of magnitude (Table 3 ).
Total PCBs and total PAHs were significantly greater in vegetated sediments but concentrations were less than proposed numerical sediment quality guidelines (SQG). In contrast, total DDT concentrations exceeded the TEL guideline (3.89 ng/g dry wt.) in vegetated sediments collected from Santa Rosa Sound near the bayou and golf complex. Concentrations (ng/g dry wt.) of DDE and DDD averaged $0.66( \pm 0.78)$ and $1.1( \pm 0.80)$, respectively, in vegetated sediments and were significantly greater than in non-vegetated sediments. Grass bed sediments collected near the bayou contained concentrations (ng/g dry wt.) of DDE (2.6) and DDD (2.4) that exceeded TEL guideline values (DDE - 2.1; DDD - 1.2).

Non-DDT pesticides were below detection, except for chlordane (Table 3). Chlordane was detected more frequently and was significantly greater in vegetated sediments. However, total chlordane concentrations were less than the proposed sediment quality guideline $(2.26 \mathrm{ng} / \mathrm{g})$, with one exception (golf complex site).

\subsubsection{Trace metals}

The differences in concentrations for the same trace metal were usually one order of magnitude or less among grass beds and between sediment types (Table 4). Chromium, copper, nickel, lead and zinc were more frequently detected in vegetated sediment (Fig. 2) and mean concentrations of chromium, zinc and total mercury were significantly greater. The greatest difference in mean concentrations for the two sediment types was for mercury. Total mercury concentrations in non-vegetated sediment, with the exception for the sample collected at a marina, were below detection $(<0.004$ $\mu \mathrm{g} / \mathrm{g}$ dry wt.). In contrast, concentrations averaged 0.009 $( \pm 0.006$; range $=0.004-0.018) \mu \mathrm{g} / \mathrm{g}$ dry wt. for six of eight vegetated samples. No individual PEL guidelines for trace metals were exceeded but individual TEL guidelines were exceeded for arsenic, copper and nickel in vegetated sediment collected from Little Sabine Bay.

SQG quotient sums (TEL) exceeded one for eight of 13 vegetated sediments and for two of 13 non-vegetated sediments (Fig. 3). SQG quotient sums based on PEL guidelines exceeded 1.0 for two of 13 vegetated sediments. 


\begin{tabular}{|c|c|c|c|c|c|c|c|c|c|c|c|c|c|}
\hline \multirow{2}{*}{\multicolumn{2}{|c|}{ Choctawhatchee Bay }} & \multirow{2}{*}{\multicolumn{2}{|c|}{ Bonito Bay }} & \multirow{2}{*}{\multicolumn{4}{|c|}{$\begin{array}{l}\text { St. Joseph Bay } \\
\text { Marina } \\
\end{array}$}} & \multirow{2}{*}{\multicolumn{2}{|c|}{ Ohio Key }} & \multirow{2}{*}{\multicolumn{2}{|c|}{ Little Duck Key }} & \multirow{2}{*}{\multicolumn{2}{|c|}{$\begin{array}{l}\text { Sediment quality guidelines } \\
\text { Bayou }\end{array}$}} \\
\hline & & & & & & & & & & & & & \\
\hline V & NV & $\mathrm{V}$ & NV & $\mathrm{V}$ & NV & $\mathrm{V}$ & NV & $\mathrm{V}$ & NV & $\mathrm{V}$ & NV & $\mathrm{TEL}^{\mathrm{a}}$ & $\mathrm{PEL}^{\mathrm{a}}$ \\
\hline 2.4 & $<1.5$ & 1.1 & $<1.5$ & $<1.5$ & $<1.5$ & 1.8 & $<1.5$ & $<1.5$ & $<1.5$ & $<1.5$ & 5.1 & 7.2 & 41.6 \\
\hline$<0.2$ & $<0.2$ & $<0.2$ & $<0.2$ & $<0.2$ & $<0.2$ & $<0.2$ & $<0.2$ & 0.39 & $<0.2$ & $<0.2$ & 0.21 & 0.68 & 4.21 \\
\hline 8.1 & 6.6 & 4.1 & $<0.2$ & 2.4 & 1.6 & 11.3 & 0.8 & 4.4 & 3.7 & 6.1 & 7.4 & 52.3 & 160 \\
\hline 12.1 & 12.7 & 1.3 & $<0.08$ & 1.5 & 3.5 & 8.0 & 1.1 & 1.4 & 1.5 & 4.8 & 2.9 & 18.7 & 108 \\
\hline- & - & $<0.004$ & $<0.004$ & - & - & - & - & - & - & - & - & 0.13 & 0.7 \\
\hline 3.3 & 3.3 & 1.2 & $<0.12$ & 1.6 & 2.3 & 4.9 & 0.6 & 8.5 & 10.7 & 10.2 & 10.1 & 15.9 & 30.2 \\
\hline 14.1 & 10.7 & 2.8 & 0.31 & 3.0 & 4.6 & 19.3 & 2.4 & 1.1 & 2.2 & 10.6 & 11.1 & 30.2 & 112 \\
\hline 40.9 & 26.7 & 5.9 & 2.4 & 7.6 & 12.3 & 50.4 & 4.6 & 3.2 & 2.8 & 7.7 & 4.5 & 124 & 271 \\
\hline$<0.5$ & $<0.5$ & $<0.5$ & 0.9 & $<0.5$ & $<0.5$ & $<0.5$ & $<0.5$ & $<0.5$ & $<0.5$ & $<0.5$ & $<0.5$ & $\mathrm{NA}^{\mathrm{b}}$ & \\
\hline$<0.05$ & $<0.05$ & $<0.05$ & $<0.05$ & $<0.05$ & $<0.05$ & $<0.05$ & $<0.05$ & $<0.05$ & $<0.05$ & $<0.05$ & $<0.05$ & NA & \\
\hline
\end{tabular}

Concentrations of arsenic, copper, lead, nickel and zinc in vegetated and non-vegetated sediments exceeded predicted background concentrations after normalization to aluminum (data not shown). Cadmium was also enriched in vegetated sediments. Enrichment for the six trace metals, as a percent of total sediment samples analyzed, ranged from 16 to $37 \%$ $(N=14$ non-vegetated sediments) and from 5 to $42 \%$ ( $N=19$ vegetated sediments).

\subsection{Seagrasses}

Concentrations of PAH compounds, PCB congeners and chlorinated pesticides were below detection in all tissues. In contrast, the 10 trace metals were detected in 16-89\% (roots and rhizomes) and 26-89\% (blades) of total samples analyzed (Table 5). Mercury, cadmium, nickel, lead, and silver were detected in $50 \%$ or more of both tissues. Spatial differences in trace metal residues for similar tissues and T. testudinum (Table 6) and $H$. wrightii (Table 7) were usually one order of magnitude or less.

Most mean trace metal concentrations, based on combined results for both species, were not significantly different between above and below substrate tissues. The exception was nickel which was statistically greater in blades. Differences in mean concentrations for the same trace metal between the two tissue types for the same species were usually two-fold or less and interspecific differences were usually three-fold or less for the same trace metal and tissue (Fig. 4). None of these differences were statistically significant.

\subsection{Bioconcentration factors (BCF)}

The BCF values based on concentrations of arsenic, chromium, copper, nickel, lead and mercury in vegetated sediment

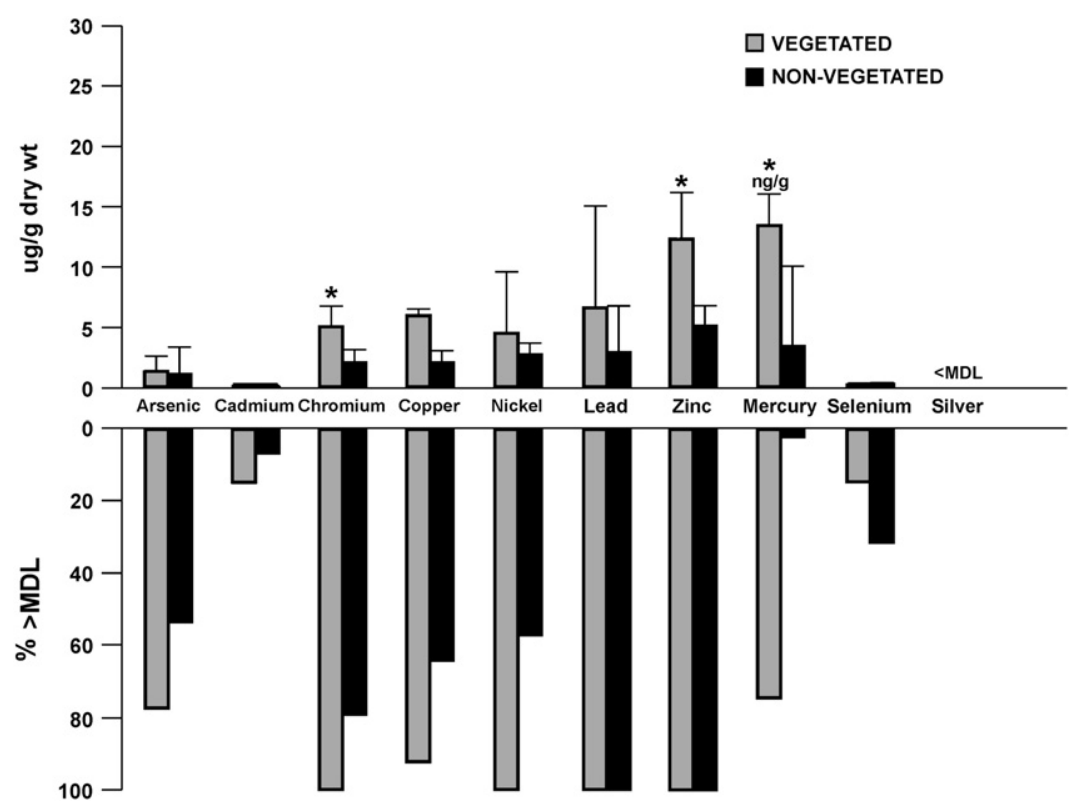

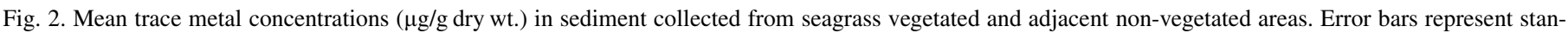
dard deviations. Percent of samples exceeding the method detection limits (> MDL) also shown. * - Significantly different. 


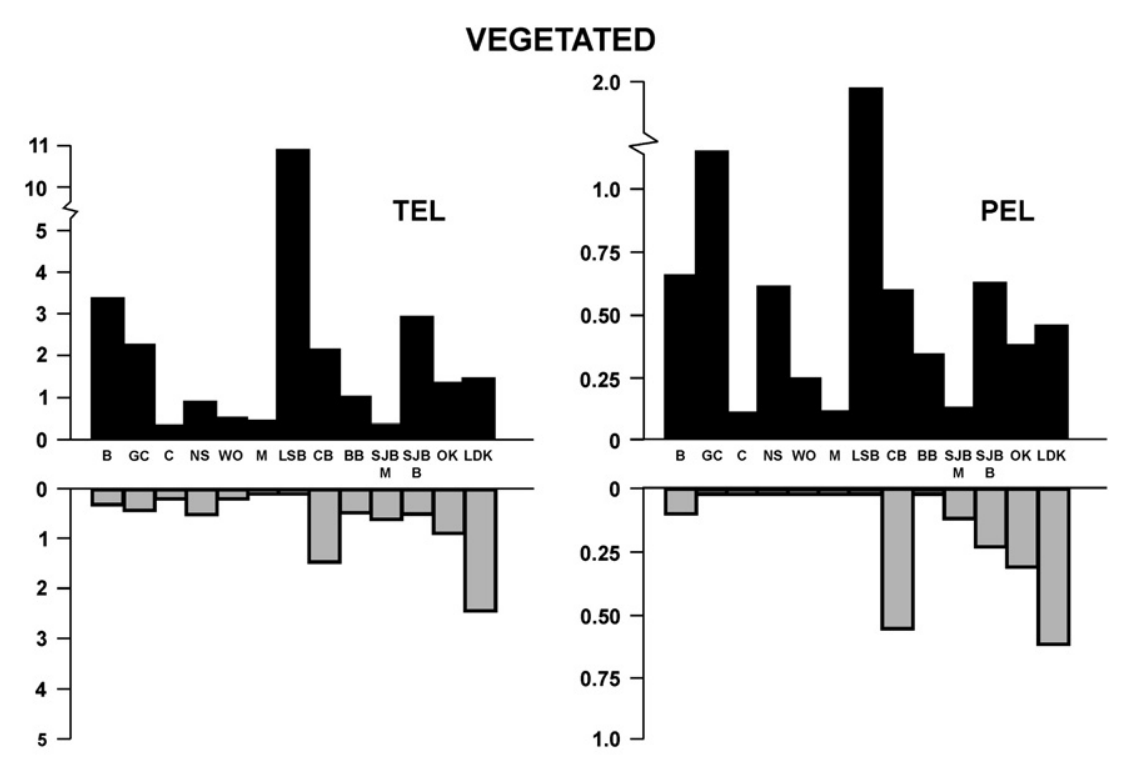

NON-VEGETATED

Fig. 3. Sum of TEL and PEL quotients for seagrass vegetated and non-vegetated sediments. Quotient sums exceeding 1.0 are considered the equivalent of the exceedance of at least one single TEL or PEL guideline based on assumption of additive chemical toxicity. See Table 1 for location designations.

and seagrass tissues ranged from $<1$ to 6 (roots and rhizomes) and from $<1$ to 11 (blades) for both species (data not shown). Approximately, $61 \%$ of the BCF values were 1 or less. The greater $\mathrm{BCF}$ values were for mercury, copper and arsenic.

BCF values based on trace metal concentrations in surface water and blades ranged from 28 to 16,667 for both seagrasses. The BCF values averaged 8772 (zinc), 2356 (nickel), 2143 (lead), 616 (chromium), 491 (cadmium), 363 (silver), 299 (selenium), 218 (copper), 91 (mercury) and 54 (arsenic).

\section{Discussion}

\subsection{Biological relevance}

The significance of the chemical concentrations in surface water, sediment and tissues on seagrass condition is unknown and its determination was beyond the scope of this baseline survey. Some insight, although limited, can be provided by comparison of the results to water quality criteria to protect marine life, proposed sediment quality guidelines and published results for phytotoxicity and tissue quality.

\subsubsection{Surface water}

Florida water quality criteria were exceeded for copper and arsenic, and less frequently for mercury, nickel and lead. These exceedances suggest the possibility of an adverse effect but uncertainty exists since the criterion values are based primarily on toxicity results for animal species, not those for seagrasses and other near-coastal, submergent vegetation.

The reported toxicity database for trace metals and seagrasses consists primarily of results determined in aqueous exposures for single metals and a limited number of test species.

Table 5

Trace metal concentrations ( $\mu \mathrm{g} / \mathrm{g}$ dry wt.) in seagrass tissues

\begin{tabular}{|c|c|c|c|c|c|c|c|c|}
\hline & \multicolumn{2}{|c|}{$\%>\mathrm{MDL}^{\mathrm{a}}$} & \multicolumn{3}{|c|}{ Roots/rhizomes } & \multicolumn{3}{|l|}{ Blades } \\
\hline & $\mathrm{R}$ & B & Mean & SD & Range & Mean & SD & Range \\
\hline Arsenic & 26 & 26 & 2.8 & 0.6 & $2.0-3.7$ & 5.7 & 2.4 & $2.6-8.2$ \\
\hline Cadmium & 68 & 74 & 0.6 & 0.3 & $0.24-1.3$ & 0.8 & 0.7 & $0.13-1.2$ \\
\hline Chromium & 63 & 42 & 1.0 & 0.9 & $0.2-2.9$ & 0.7 & 1.1 & $0.13-3.5$ \\
\hline Copper & 16 & 37 & 10.8 & 3.9 & $8.3-15.3$ & 9.3 & 5.1 & $5.9-20.5$ \\
\hline Nickel & 63 & 63 & 1.1 & 0.6 & $0.6-2.7$ & 2.6 & 0.8 & $1.2-3.5$ \\
\hline Lead & 63 & 63 & 1.3 & 1.1 & $0.25-4.1$ & 1.7 & 1.4 & $0.3-4.8$ \\
\hline Mercury ${ }^{b}$ & 89 & 89 & 10.8 & 3.7 & $6-19$ & 17.9 & 6.9 & $12-38$ \\
\hline Zinc & 47 & 37 & 16.5 & 23.8 & $2.5-64.0$ & 14.7 & 25.7 & $3.4-73.0$ \\
\hline Selenium & 47 & 47 & 1.5 & 0.3 & $1.0-1.9$ & 1.9 & 0.4 & $1.1-2.5$ \\
\hline Silver & 58 & 63 & 0.25 & 0.15 & $0.13-0.68$ & 0.5 & 0.2 & $0.21-0.63$ \\
\hline
\end{tabular}

Values represent mean $( \pm 1$ standard deviation) for both seagrass species.

${ }^{a}$ Percent of 19 samples for each tissue exceeding method detection limit (MDL): roots/rhizomes (R), blades (B).

${ }^{b}$ Percent of 12 samples in ng/g dry wt. 
Table 6

Trace metal concentrations ( $\mu \mathrm{g} / \mathrm{g}$ dry wt.) in roots/rhizomes (R) and blades (B) of Thalassia testudinum

\begin{tabular}{|c|c|c|c|c|c|c|c|c|c|c|c|c|c|c|c|c|c|c|}
\hline \multirow[t]{3}{*}{ Trace metals } & \multicolumn{10}{|c|}{ Santa Rosa Sound } & \multirow{2}{*}{\multicolumn{2}{|c|}{ Little Sabine Bay }} & \multirow{2}{*}{\multicolumn{2}{|c|}{ Bonito Bay }} & \multirow{2}{*}{\multicolumn{2}{|c|}{$\begin{array}{l}\text { St. Joseph } \\
\text { Bay Marina }\end{array}$}} & \multirow{2}{*}{\multicolumn{2}{|c|}{ Little Duck Key }} \\
\hline & \multicolumn{2}{|l|}{ Canal } & \multicolumn{2}{|l|}{ Bayou } & \multicolumn{2}{|c|}{ Golf Complex } & \multicolumn{2}{|c|}{ National Seashore } & \multicolumn{2}{|l|}{ Marina } & & & & & & & & \\
\hline & $\mathrm{R}$ & $\mathrm{B}$ & $\mathrm{R}$ & B & $\mathrm{R}$ & B & $\mathrm{R}$ & B & $\mathrm{R}$ & B & $\mathrm{R}$ & $\mathrm{B}$ & $\mathrm{R}$ & B & $\mathrm{R}$ & B & $\mathrm{R}$ & B \\
\hline Arsenic & $<2$ & $<2$ & $<2$ & $<2$ & 2.6 & 8.2 & $<2$ & $<2$ & $<2$ & $<2$ & 2.0 & $<2$ & $<2$ & $<2$ & $<2$ & $<2$ & $<2$ & $<2$ \\
\hline Cadmium & 0.7 & 0.8 & 0.6 & 1.2 & 1.3 & 0.6 & 0.7 & 0.8 & 0.9 & 0.9 & 0.6 & 0.9 & 0.5 & 0.7 & $<0.1$ & 0.11 & $<0.1$ & $<0.1$ \\
\hline Chromium & 0.5 & 0.1 & 0.5 & $<0.1$ & 0.5 & 0.2 & 0.3 & $<0.1$ & 0.8 & 0.1 & 0.2 & $<0.1$ & 0.4 & $<0.1$ & $<5$ & $<5$ & $<5$ & $<5$ \\
\hline Copper & $<5$ & 7.1 & $<5$ & 8.2 & $<5$ & 5.9 & $<5$ & $<5$ & $<5$ & 20.5 & 15.3 & $<5$ & $<5$ & $<5$ & $<5$ & $<5$ & $<5$ & $<5$ \\
\hline Mercury & 0.009 & 0.018 & 0.007 & 0.014 & 0.009 & 0.014 & - & - & 0.010 & 0.019 & 0.006 & 0.014 & 0.010 & 0.020 & - & - & - & - \\
\hline Nickel & 0.6 & 3.5 & 0.8 & 2.8 & 0.7 & 2.1 & 0.6 & 3.1 & 1.1 & 3.0 & 0.6 & 1.9 & 0.9 & 3.4 & $<1$ & $<1$ & $<1$ & $<1$ \\
\hline Lead & 0.3 & 0.3 & 0.3 & 0.4 & 0.9 & 3.7 & 0.4 & 0.7 & 1.0 & 1.7 & 1.9 & 0.6 & 1.3 & 1.1 & $<1$ & $<1$ & $<1$ & $<1$ \\
\hline Zinc & $<50$ & $<50$ & $<50$ & $<50$ & $<50$ & $<50$ & $<50$ & $<50$ & 52 & 73 & $<50$ & $<50$ & $<50$ & $<50$ & 8.4 & 6.1 & 3.0 & 4.8 \\
\hline Selenium & 1.3 & 1.6 & 1.6 & 1.7 & 1.6 & 2.2 & 1.0 & $<1.0$ & 1.2 & $<1.0$ & 1.3 & $<1.0$ & $<1.0$ & $<1.0$ & $<1.0$ & $<1.0$ & $<1.0$ & $<1.0$ \\
\hline Silver & 0.2 & 0.5 & 0.3 & 0.6 & 0.3 & 0.6 & 0.2 & 0.6 & 0.7 & 0.5 & 0.2 & 0.5 & 0.2 & 0.4 & $<0.1$ & $<0.1$ & $<0.1$ & $<0.1$ \\
\hline
\end{tabular}

Values are for one composite sample for each location. No data $(-)$.

Table 7

Trace metal concentrations ( $\mu \mathrm{g} / \mathrm{g}$ dry wt.) in roots/rhizomes (R) and blades (B) of Halodule wrightii

\begin{tabular}{|c|c|c|c|c|c|c|c|c|c|c|c|c|c|c|c|c|c|c|}
\hline \multirow[t]{3}{*}{ Trace metal } & \multicolumn{8}{|c|}{ Santa Rosa Sound } & \multirow{2}{*}{\multicolumn{2}{|c|}{ Choctawhatchee Bay }} & \multirow{2}{*}{\multicolumn{2}{|c|}{ Bonito Bay }} & \multicolumn{4}{|c|}{ St. Joseph Bay } & \multirow{2}{*}{\multicolumn{2}{|c|}{ Ohio Key }} \\
\hline & \multicolumn{2}{|l|}{ Bayou } & \multicolumn{2}{|c|}{ Golf Complex } & \multicolumn{2}{|c|}{ National Seashore } & \multicolumn{2}{|c|}{ Wastewater Outfall } & & & & & Bayo & & Marin & & & \\
\hline & $\mathrm{R}$ & B & $\mathrm{R}$ & B & $\mathrm{R}$ & B & $\mathrm{R}$ & B & $\mathrm{R}$ & $\mathrm{B}$ & $\mathrm{R}$ & B & $\mathrm{R}$ & B & $\mathrm{R}$ & B & $\mathrm{R}$ & B \\
\hline Arsenic & 2.7 & 3.8 & 3.7 & 6.3 & $<2$ & 2.6 & $<2$ & $<2$ & $<2$ & $<2$ & 3.1 & 7.4 & $<2$ & $<2$ & $<2$ & $<2$ & $<2$ & $<2$ \\
\hline Cadmium & 0.4 & 0.4 & 0.4 & 0.5 & 0.4 & 0.4 & 0.4 & 0.3 & $<0.1$ & $<0.1$ & 0.2 & 0.3 & $<0.1$ & $<0.1$ & $<0.1$ & $<0.1$ & 0.12 & 0.13 \\
\hline Chromium & 2.9 & 0.6 & 2.4 & 0.6 & 2.0 & 0.2 & 0.3 & 3.5 & $<5$ & $<5$ & 0.6 & 0.4 & $<5$ & $<5$ & $<5$ & $<5$ & $<5$ & $<5$ \\
\hline Copper & 8.3 & 7.5 & 8.7 & 6.7 & $<5$ & $<5$ & $<5$ & 9.1 & $<5$ & $<5$ & $<5$ & $<5$ & $<5$ & $<5$ & $<5$ & $<5$ & $<5$ & $<5$ \\
\hline Mercury & 0.013 & 0.012 & 0.016 & 0.013 & 0.012 & 0.020 & 0.019 & 0.038 & - & - & 0.009 & 0.017 & - & - & - & - & - & - \\
\hline Nickel & 1.3 & 2.2 & 1.9 & 2.8 & 1.3 & 1.2 & $<1$ & 3.5 & $<1$ & $<1$ & 2.7 & 1.8 & $<1$ & $<1$ & $<1$ & $<1$ & $<1$ & $<1$ \\
\hline Lead & 1.3 & 1.2 & 2.2 & 2.7 & 1.1 & 1.3 & $<1$ & 1.5 & $<1$ & $<1$ & 4.1 & 4.8 & $<1$ & $<1$ & $<1$ & $<1$ & $<1$ & $<1$ \\
\hline Zinc & $<50$ & $<50$ & $<50$ & $<50$ & $<50$ & $<50$ & $<50$ & $<50$ & 2.9 & 3.5 & $<50$ & $<50$ & 6.8 & 6.1 & 6.0 & 6.2 & 2.5 & 3.4 \\
\hline Selenium & 1.6 & 2.5 & 1.9 & 2.3 & 1.6 & 1.7 & $<1.0$ & 1.9 & $<1.0$ & $<1.0$ & $<1.0$ & 1.4 & $<1.0$ & $<1.0$ & $<1.0$ & $<1.0$ & $<1.0$ & $<1.0$ \\
\hline Silver & 0.18 & 0.29 & $<0.1$ & 0.21 & 0.19 & 0.65 & 0.13 & 0.23 & 0.14 & $<0.1$ & $<0.1$ & 0.32 & $<0.1$ & $<0.1$ & $<0.1$ & $<0.1$ & $<0.1$ & $<0.1$ \\
\hline
\end{tabular}

Values are for one composite sample for each location. No data $(-)$. 


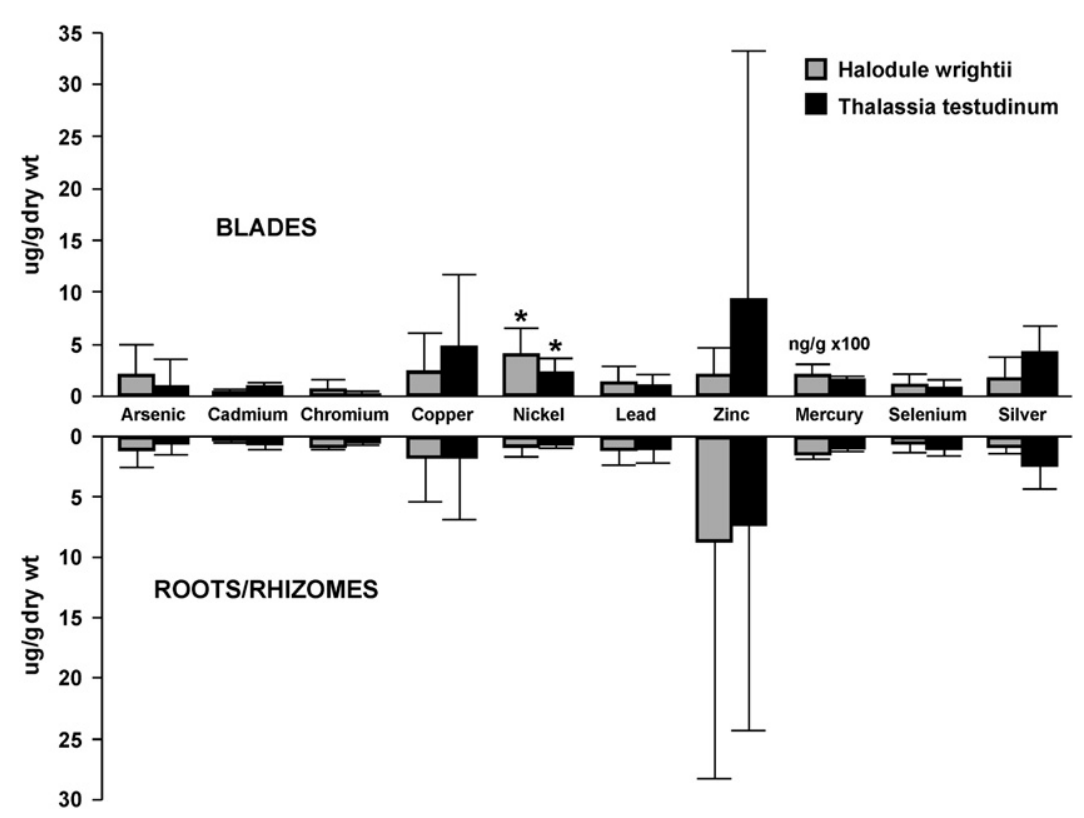

Fig. 4. Mean trace metal residues ( $\mu \mathrm{g} / \mathrm{g}$ dry wt.) in above and below substrate tissues of Halodule wrightii and Thalassia testudinum. Error bars represent standard deviations. * - Significant difference between mean concentrations in tissues for same species.

There has been no consistency in experimental design. No toxicity data have been reported for chemicals monitored in this survey and $T$. testudinum and $H$. wrightii. However, trace metal concentrations in surface waters determined in this survey are less than most laboratory-derived toxic concentrations reported for corresponding metals and other seagrasses. For example, toxic concentrations have typically exceeded $100 \mu \mathrm{g} / \mathrm{L}$ for zinc, copper, cadmium and lead and several species of Halophila, Halodule, Zostera and Posidonia based on changes in photosynthetic activity, pigment content, growth rate and amino acid content (Conroy et al., 1991; Malea et al., 1995a,b; Ralph and Burchett, 1998; Hamoutene et al., 1996; Prange and Dennison, 2000; Macinnis-Ng and Ralph, 2002). The maximum concentrations $(\mu \mathrm{g} / \mathrm{L})$ in this survey were 66.4 (zinc), 61.1 (copper) and 16.7 (lead).

\subsubsection{Sediments}

Exceedances of individual TEL guidelines occurred for vegetated sediments collected from three grass beds for total DDT, DDD, DDE, total chlordane, arsenic, copper and nickel and for one grass bed based on the PEL guideline for chlordane. The effects of these exceedances on seagrass condition and survival are not known. As for water quality criteria, the proposed guideline concentrations are based primarily on effects data for benthic macroinvertebrates and not on that for coastal submergent vegetation. Furthermore, toxicities of chemical-spiked sediments to seagrasses are not available in the scientific literature for comparison.

\subsubsection{Seagrass tissues}

The biological impact of the concentrated chemicals is unknown. Critical tissue burdens for most anthropogenic chemicals are unavailable for $T$. testudinum and $H$. wrightii, or any other species to provide insight. The lack of a tissue residue- effects database is an important limitation to the interpretation of the many published reports describing the magnitude of seagrass-accumulated chemicals.

\subsection{Data comparisons}

\subsubsection{Surface water}

Concentrations of copper, chromium, cadmium, lead, zinc and mercury have been detected in surface waters over other seagrass beds (Perez, 1995; Malea and Haritonidis, 1995; Pergent-Martini, 1998; Campanella et al., 2001). Concentrations of copper, chromium, lead and zinc in this survey were often similar to these previously reported values. For example, copper concentrations between 23 and $74 \mu \mathrm{g} / \mathrm{L}$ have been reported over grass beds in the Gulf of Antikyra (Malea and Haritonidis, 1995) compared to a range of $13.9-61.1 \mu \mathrm{g} / \mathrm{L}$ for this study. In contrast, cadmium $(<1.0 \mu \mathrm{g} / \mathrm{L})$ and mercury (range $=<0.2-0.38 \mu \mathrm{g} / \mathrm{L}$ ) in this survey were sometimes less than concentrations reported in the above studies which ranged from 0.2 to $1.5 \mu \mathrm{g} / \mathrm{L}$ (cadmium) and from 1.0 to $3.0 \mu \mathrm{g} / \mathrm{L}$ (mercury), respectively.

\subsubsection{Sediments}

Trace metal concentrations in seagrass vegetated sediments in this survey were also within the wide range of those reported for other grass bed sediments. For example, concentrations of $\mathrm{Cd}$ (range $=0.1-87), \mathrm{Cu}$ (3-397), chromium (105-678), nickel $(61-889)$, lead $(2-633)$ and zinc $(<10-16,700)$ have been reported for various grass bed sediments located in Australia, Brazil, Greece, Italy and the U.S. (Ward et al., 1986; Lacerda and Resende, 1986; Cornwell and Stevenson, 1990; Malea and Haritonidis, 1995; Nicolaidou and Nott, 1998; Schlacher-Hoenlinger and Schlacher, 1998). 
Reported concentrations of organic contaminants in grass bed sediments are uncommon. Haynes et al. (2000) reported the concentrations of several pesticides in sediments associated with the Great Barrier Reef. Concentrations in subtidal sediments (ng/g dry wt.) ranged from $<0.1$ to 0.3 (atrazine), $<0.05$ to 0.37 (dieldrin), $<0.05$ to 0.05 (DDT), $<0.05$ to 0.25 (DDE) and $<0.1$ to 9.8 (diuron). Of these, only DDT (range $=<\mathrm{MDL}$ to $1.29 \mathrm{ng} / \mathrm{g}$ ) and $\mathrm{DDE}$ (range $=<\mathrm{MDL}$ to $2.55 \mathrm{ng} / \mathrm{g}$ ) were detected in vegetated sediments in this study. Chlorinated pesticides and PCBs were below detection in vegetated sediments collected from Chesapeake Bay but total DDT concentrations of 0.08 and $0.09 \mathrm{ng} / \mathrm{g}$ dry wt. were observed (Cornwell and Stevenson, 1990). These total DDT concentrations were less than those observed in this study (range $=0.1-10.3 \mathrm{ng} / \mathrm{g}$ dry wt.).

\subsubsection{Seagrass tissues}

Trace metal residues in this survey, with few exceptions, are intermediate to those reported for other seagrasses (Table 8). Concentrations of selenium and arsenic in this survey were less than those reported for Posidonia australis (Jervis Bay, Australia) and T. testudinum (Gulf of Mexico), respectively (Baldwin et al., 1996; Fourqurean and Cai, 2001). Total mercury concentrations (ng/g dry wt.) were between 12 and 38 (blades) and between 6 and 19 (roots and rhizomes) in this survey. Mean mercury concentrations (ng/g dry wt.) in leaves and rhizomes of Posidonia oceanica collected from the Mediterranean Sea ranged between 10 and 177 and from 30 to 52, respectively (Pergent-Martini, 1998). Mercury residues (ng/g dry wt.) in Thalassia collected from Venezuelan coastal waters were between 8 and 43 (rhizomes) and between 4 and 30 (leaves) (Perez, 1995).

Concentrations of organic contaminants in seagrass tissues have been below detection in the few reported studies. This was the case in this study for most of these chemicals and also for three Australian seagrass species (Haynes et al., 2000).

\subsubsection{Tissue and interspecific comparisons}

Differential tissue bioaccumulation as observed for nickel in this survey, has been frequently reported for other seagrasses and trace metals. Although not observed during this survey, cadmium, copper and zinc have been found more concentrated in leaves and concentrations of chromium, copper, iron and lead found greater in rhizomes of several seagrass species (Lacerda and Resende, 1986; Warnau et al., 1995; Schlacher-Hoenlinger and Schalcher, 1998; Prange and Dennison, 2000).

Interspecific differences in residues for similar tissues in this survey were less than an order of magnitude. This result is similar to that reported by Catsiki and Panayotidis (1993) for copper and nickel residues in leaves, roots and rhizomes of P. oceanica and Cymodocea nodosa collected from Greek coastal areas and for five trace metals and five seagrass species collected from Australian coastal waters (Prange and Dennison, 2000).

\section{Summary and conclusions}

Anthropogenic chemicals concentrated in seagrass tissues and their rooted sediments varied two orders of magnitude or less among 13 Florida grass beds and, with few exceptions, were within the wide range of concentrations reported previously in the scientific literature for other grass beds. Vegetated sediments contained greater concentrations of some contaminants than non-vegetated sediments, although metal enrichment was common for both types. The biological significance of the chemical concentrations in surface water, sediment and seagrass tissues is largely unknown due to the lack of published information describing their phytotoxicities and tissue-residue effects. In addition, the relevance of the sometimes exceedance of current regulatory criteria and guidelines observed for water and sediment during this survey is unknown due to the uncertainties associated with their faunal-dominated supporting databases.

More fate and effects information is available for seagrasses characteristic of the North Atlantic, Indo-Pacific and Australian floras than for the seagrasses common to the Gulf of Mexico (Lewis and Devereux, submitted for publication). This limited perspective is surprising since large scale losses of seagrasses have occurred in the Gulf of Mexico. The cause of these losses, at least in part, may be the large amount of point and non-point source contaminants entering near-shore areas of the Gulf of Mexico, the most of any coastal zone. Therefore, the determination of media-specific toxicological data for commonly occurring seagrasses and contaminants in shoreline areas needs increased attention not only for the risk assessment process, but also to judge the relevance of current water quality criteria and sediment quality guidelines to protect seagrasses and other benthic vascular plants. These data should be derived with consideration of the naturally variable habitat conditions of seagrasses (water clarity, salinity, temperature) and the likely co-occurrence of multiple potentially inhibitory and stimulatory chemicals. Until this information is available, the role of non-nutrient anthropogenic chemicals as a contributing factor, alone or in combination with other stressors, to the continuing decline in condition, abundance and distribution of these perennial angiosperms in most Gulf coastal areas will remain uncertain.

\section{Disclaimer}

The U.S. Environmental Protection Agency through its Office of Research and Development funded and managed the research described here. It has been subjected to the Agency's peer and administrative review and has been approved for publication as an EPA document.

\section{Acknowledgments}

The authors thank Peggy Rogers (NCBA) for preparation of the manuscript and Stephen Embry (CSC Corporation) for graphic support. Analyses of seagrass and sediment were 
Table 8

Examples of reported trace metal concentrations ( $\mu \mathrm{g} / \mathrm{g}$ dry wt.) in seagrass tissues

\begin{tabular}{|c|c|c|c|c|c|c|c|c|c|}
\hline \multirow[t]{2}{*}{ Tissue } & \multirow[t]{2}{*}{ Species } & \multicolumn{6}{|l|}{ Trace metal } & \multirow[t]{2}{*}{ Location } & \multirow[t]{2}{*}{ Reference } \\
\hline & & $\mathrm{Cd}$ & $\mathrm{Cu}$ & $\mathrm{Cr}$ & $\mathrm{Ni}$ & $\mathrm{Pb}$ & $\mathrm{Zn}$ & & \\
\hline \multirow[t]{12}{*}{ Blades } & Zostera marina & $0.9-2.9$ & $1.9-16.6$ & - & - & $0.5-38$ & $41-175$ & Limfjord (Denmark) & Brix et al. (1983) \\
\hline & Posidonia oceanica & - & $0.4-46$ & $0.05-37$ & $2-61$ & - & - & Aegean Sea (Greece) & Catsiki and Panayotidis \\
\hline & Cymodocea nodosa & - & $0.4-44$ & $0.05-7$ & $3-49$ & - & - & & $(1993)$ \\
\hline & Posidonia oceanica & $3-44$ & $3-148$ & - & - & $11-123$ & $27-98$ & Gulf of Antikyra (Greece) & Malea et al. (1994) \\
\hline & $\begin{array}{l}\text { Posidonia oceanica } \\
\text { Cymodocea nodosa }\end{array}$ & $2.1-2.4$ & $10-16$ & $1-2$ & - & $6-8$ & $144-179$ & NW Mediterranean Sea & Warnau et al. (1995) \\
\hline & - Reference areas & 1 & 10 & 2 & 8 & - & 58 & Bay of Laryma (Greece) & Nicolaidou and Nott (1998) \\
\hline & - Polluted areas & 2 & 24 & 5 & 77 & - & 147 & & \\
\hline & Zostera capricorni & - & $8-12$ & $6-31$ & - & - & $24-75$ & Port Curtis (Australia) & Prange and Dennison (2000) \\
\hline & Posidonia oceanica & $0.6-1.3$ & $6-17$ & - & - & 5 & - & Liscia Bay (Italy) & Baroli et al. (2001) \\
\hline & Posidonia oceanica & $1-3$ & $6-20$ & $0.3-0.9$ & - & $1-10$ & $105-155$ & Favignana Island (Italy) & Campanella et al. (2001) \\
\hline & Thalassia testudinum & $<0.1-1.2$ & $<5-20.5$ & $<0.1-0.2$ & $<1-3.5$ & $0.3-3.7$ & $4.8-7.3$ & Gulf of Mexico (USA) & This study \\
\hline & Halodule wrightii & $<0.1-0.5$ & $<5-9.1$ & $0.2-3.5$ & $<1-3.5$ & $<1-4.8$ & $3.4-6.2$ & & \\
\hline \multirow[t]{12}{*}{ Roots and Rhizomes } & Zostera marina & $0.1-1.0$ & $2-19$ & - & - & $0.4-30$ & $25-125$ & Limfjord (Denmark) & Brix et al. (1983) \\
\hline & Halodule wrightii & - & $6-19$ & - & - & $11-24$ & $71-110$ & Sepetiba Bay (Brazil) & Lacerda and Resende (1986) \\
\hline & Posidonia oceanica & - & $0.3-59$ & $0.05-25$ & $2-46$ & - & - & Aegean Sea (Greece) & Catsiki and Panayotidis \\
\hline & Cymodocea nodosa & - & $0.2-75$ & $1-34$ & $1-50$ & - & - & & $(1993)$ \\
\hline & $\begin{array}{l}\text { Posidonia oceanica } \\
\text { Cymodocea nodosa }\end{array}$ & $0.7-1.7$ & $8-22$ & $2-3$ & - & $10-15$ & $95-112$ & NW Mediterranean Sea & Warnau et al. (1995) \\
\hline & - Reference areas & 2 & 13 & 5 & 5 & - & 23 & Bay of Larymna (Greece) & Nicolaidiou and Nott (1998) \\
\hline & - Polluted areas & 3 & 22 & 11 & 26 & - & 62 & & \\
\hline & Zostera capricorni & - & $2-14$ & $5-30$ & - & - & $8-60$ & Port Curtis (Australia) & Prange and Dennison (2000) \\
\hline & Posidonia oceanica & $0.8-2.4$ & $5.4-15.3$ & - & - & $0.8-2.4$ & - & Liscia Bay (Italy) & Baroli et al. (2001) \\
\hline & Posidonia oceanica & $0.4-1.0$ & $7-15$ & $0.9-1.4$ & - & $3-17$ & $41-140$ & Favignana Island (Italy) & Campanella et al. (2001) \\
\hline & Thalassia testudinum & $<0.1-1.3$ & $<5-15.3$ & $0.2-0.8$ & $0.6-1.1$ & $0.3-1.9$ & $3.0-52$ & Gulf of Mexico (USA) & This study \\
\hline & Halodule wrightii & $0.12-0.4$ & $<5-8.7$ & $0.3-2.9$ & $<1-2.7$ & $<1-4.1$ & $2.5-6.8$ & & \\
\hline
\end{tabular}

Values usually represent range of individual values or mean values. For additional perspective, see reviews by Williams et al. (1994), Malea and Haritonidis (1995), Schlacher-Hoenlinger and Schlacher (1998) and Campanella et al. (2001) 
performed by Midwest Research Institute (Kansas City, MO) and B\&B Laboratories (College Station, TX).

\section{References}

American Public Health Association, American Water Works Association, Water Environment Federation, 1995. Standard Methods for the Examination of Water and Wastewater, nineteenth ed. American Public Health Association, Washington, DC.

Baldwin, S., Maher, W., Kleber, E., Krikowa, F., 1996. Selenium in marine organisms of seagrass habitats of Jervis Bay, Australia. Marine Pollution Bulletin 32, 310-316.

Baroli, M., Cristini, A., Cossi, A., DeFalco, G., Gazale, V., PergentMartini, A., Pergent, G., Faranda, F.M., Guglielmo, L., Spezie, G., 2001. Concentrations of trace metals in Posidonia oceanica seagrass of Liscia Bay, Sardinia (Italy). Mediterranean Ecosystems: Structures and Processes. Springer-Verlag, Italy, pp. 95-99.

Bester, K., 2000. Effects of pesticides on seagrass beds. Helgot Marine Research 54, 95-98.

Bologna, P.A.X., Haywick, D., 2002. Assessment of seagrass plant demography within and among beds of turtle grass (Thalassia testudinum), manatee grass (Syringodium filforme) and shoal grass (Halodule wrightii) from the Northern Gulf of Mexico. Gulf of Mexico Science 2, 135-150.

Brix, H., Lyngby, J.E., Schierup, H.H., 1983. Eelgrass (Zostera marina L.) as an indicator organism of trace metals in the Limfjord, Denmark. Marine Environmental Research 8, 165-181.

Campanella, L., Conti, M.E., Cubadda, F., Sucapane, C., 2001. Trace metals in seagrass, algae and molluses from an uncontaminated area in the Mediterranean. Environmental Pollution 111, 117-126.

Catsiki, V.A., Panayotidis, P., 1993. Copper, chromium and nickel in tissues of the Mediterranean seagrasses Posidonia oceanica and Cymodocea nodosa from Greek coastal areas. Chemosphere 26, 963-978.

Conroy, B.A., Lake, P., Buchhorn, N., McDouall-Hill, J., Hughes, L., 1991. Studies on the effects of heavy metals on seagrasses in Lake Macquarie. In: Whitehead, J.H., Kidd, R.W., Bridgman, H.A. (Eds.), Lake Macquarie: an Environmental Reappraisal. University of Newcastle, Newcastle, pp. $55-65$.

Cornwell, J.C., Stevenson, J.C., 1990. Toxic substances in submerged aquatic vegetation beds. Horn Point Environmental Laboratories, University of Maryland, Cambridge, MD. 8 pp.

Dawes, C.J., Hall, M.O., Riechert, R.K., 1985. Seasonal biomass and energy content in seagrass communities on the west coast of Florida. Journal of Coastal Research 1, 255-262.

Dawes, C., Phillips, R.C., Morrison, G., 2004. Seagrass communities of the Gulf Coast of Florida: status and ecology. Tampa Bay Estuary Program, St. Petersburg, FL.

Duarte, C.M., 1999. Seagrass ecology at the turn of the millennium: challenges for the new century. Aquatic Botany 65, 7-20.

Erskine, J.M., Koch, M.S., 2000. Sulfide effects on Thalassia testudinum carbon balance and adenylate energy charge. Aquatic Botany 67, 275-285.

Fletcher, S.W., Fletcher, S.W., 1995. Factors affecting changes in seagrass distribution and diversity patterns in the Indian River Lagoon complex between 1940 and 1992. Bulletin of Marine Science 57, 49-58.

Florida Department of Environmental Protection, 1994. Approach to the assessment of sediment quality in coastal waters. In: Development and Evaluation of Sediment Quality Guidelines, vol. 1. Florida Department of Environmental Protection, Tallahassee, FL.

Florida Department of Environmental Protection, 1996. Chapter 62-302 of the Florida Administration Code Rule: 62-302, 530(45). Tallahassee, FL.

Fourqurean, J.W., Cai, Y., 2001. Arsenic and phosphorus in seagrass leaves from the Gulf of Mexico. Aquatic Botany 71, 247-258.

Fourqurean, J.W., Durako, M.J., Hall, M.O., Hefty, L.N., 2002. Seagrass distribution in South Florida: a multi-agency coordinated monitoring program. In: Porter, J.W., Porter, K.G. (Eds.), The Everglades, Florida Bay and Coral Reefs of the Florida Keys: an Ecosystem Source Book. CRC Press, Boca Raton, FL, pp. 497-522.
Frankovich, T.A., Zieman, J.C., 1994. Total epiphyte and epiphytic carbonate production of Thalassia testudinum across Florida Bay. Bulletin of Marine Science 54, 679-695.

Hall, M.O., Bell, S.S., 1993. Meiofauna seagrass Thalassia testudinum: population characteristics of harpacticoid copepods and associations with algal epiphytes. Marine Biology 116, 137-146.

Hall, M.O., Durako, M.J., Fourqurean, J.W., Zieman, J.C., 1999. Decadal changes in seagrass distribution and abundance in Florida Bay. Estuaries $22,445-459$.

Hamoutene, D., Romeo, M., Gnassia, M., Lafaurie, M., 1996. Cadmium effects of oxidative metabolism in a marine seagrass: Posidonia oceanica. Bulletin of Environmental Contamination and Toxicology 56, 327-334.

Haynes, D., Muller, J., Carter, S., 2000. Pesticide and herbicide residues in sediments and seagrasses from the Great Barrier Reef World Heritage area and Queensland coast. Marine Pollution Bulletin 41, 279-287.

Hemminga, M.A., Duarte, C.M., 2000. Seagrass Ecology. Cambridge University Press, Cambridge, 298 pp.

Irlandi, E., Orlando, B., Macia, S., Biber, P., Jones, T., Kaufman, L., Lirman, D., Patterson, E.T., 2002. The influence of freshwater runoff on biomass, morphometrics and production of Thalassia testudinum. Aquatic Botany 72, 67-78.

Iverson, R.L., Bittaker, H.F., 1986. Seagrass distribution and abundance in eastern Gulf of Mexico coastal waters. Estuarine Coastal Shelf Science $22,577-602$.

Jackson, E.L., Rowden, A.A., Attrill, M.J., Bossey, S.J., Jones, M.B., 2001. The importance of seagrass beds as a habitat for fishery species. Oceanography and Marine Biology: an Annual Review 39, 269-303.

Koch, M.S., Erskine, J.M., 2001. Sulfide as a phytotoxin to the tropical seagrass Thalassia testudinum: interactions with light, salinity and temperature. Journal of Experimental Marine Biology and Ecology 266, $81-95$.

Lacerda, L.D., Resende, C.E., 1986. Effect of metals on the seagrass Halodule wrightii Aschers during one growing season. Revista Brasileira de Botânica 9, 87-90.

Lewis, M.A., Devereux, R. A synoptic review of the role of anthropogenic chemicals in seagrass declines. Estuaries, submitted for publication.

Livingston, R.L., McGlynn, S.E., Niu, X., 1998. Factors controlling seagrass growth in a gulf coastal system: water and sediment quality and light. Aquatic Botany 60, 135-159.

Long, E.R., Field, L.J., MacDonald, D.D., 1998. Predicting toxicity in marine sediments with numerical sediment quality guidelines. Environmental Toxicology and Chemistry 17, 714-727.

MacDonald, D.D., Carr, R.S., Calder, F.D., Long, E.R., Ingersoll, C.G., 1996. Development and evaluation of sediment quality guidelines for Florida coastal waters. Ecotoxicology 5, 253-278.

Macinnis-Ng, C.M.O., Ralph, P.J., 2002. Towards a more ecologically relevant assessment of the impact of heavy metals on the photosynthesis of the seagrass Zostera capricorni. Marine Pollution Bulletin 45, 100-106.

Malea, P., Haritonidis, S., Kevrekidis, T., 1994. Seasonal and local variations of metal concentrations in the seagrass Posidonia oceanica (L.) Delile in the Antikyra Gulf, Greece. The Science of the Total Environment 153, 225-235.

Malea, P., Kevrekidis, T., Haritonidis, T., 1995a. The short-term uptake of copper by two parts of seagrass, Halophila stipulacea (Forsk). Aschers and leaf cell viability. Fresenius Environmental Bulletin 4, 117-122.

Malea, P., Kenrekidis, T., Haritonidis, S., 1995b. The short-term uptake of zinc and cell mortality of the seagrass Halophila stipulacea (Forsk.) Aschers: Israel. Journal of Plant Sciences 43, 21-30.

Malea, P., Haritonidis, S., 1995. Local distribution and seasonal variation of $\mathrm{Fe}, \mathrm{Pb}, \mathrm{Zn}, \mathrm{Cu}, \mathrm{Cd}, \mathrm{Na}, \mathrm{K}, \mathrm{Ca}$ and $\mathrm{Mg}$ concentrations in the seagrass $C y m-$ odocea nodosa (Ucria) Aschers in the Antikyra Gulf (Greece). P.S.Z.N.I. Marine Ecology 16, 41-56.

Matheson Jr., R.E., Camp, D.K., Sogard, S.M., Bjorgo, K.A., 1999. Changes in seagrass-associated fish and crustacean communities on Florida Bay mud banks: the effects of recent ecosystem changes. Estuaries 22, 534-551.

Nicolaidou, A., Nott, J.A., 1998. Metals in sediment, seagrass and gastropods near a nickel smelter in Greece: possible interactions. Marine Pollution Bulletin 5, 360-365

Pait, A.S., DeSouza, A.E., Farrow, D.R.G., 1992. Agricultural Pesticide Use in Coastal Areas: a National Summary. NOAA, Rockville, MD. 
Pergent-Martini, C., 1998. Posidonia oceanica: a biological indicator of past and present mercury contamination in the Mediterranean Sea. Marine Environmental Research 45, 101-111.

Perez, D., 1995. Mercurial pollution in the seagrass Thalassia testudinum (Banks and König). Bulletin of Marine Science 56, 707-710.

Peters, E.C., Gassman, N.J., Furman, J.C., Richmond, R.H., Power, E.A., 1997. Ecotoxicology of tropical marine ecosystems. Environmental Toxicology and Chemistry 16, 12-40.

Prange, J.A., Dennison, W.C., 2000. Physiological responses of five seagrasses species to trace metals. Marine Pollution Bulletin 41, 327-336.

Ralph, P.J., 2000. Herbicide toxicity of Halophila ovalis assessed by chlorophyll $a$ fluorescence. Aquatic Botany 66, 141-152.

Ralph, P.J., Burchett, M.D., 1998. Photosynthetic response of Halopila ovalis to heavy metal stress. Environmental Pollution 103, 91-101.

SAS Institute Inc., 1991. SAS/STAT Users Guide. Version 6, fourth ed. SAS Institute Inc., Cary, NC.

Schlacher-Hoenlinger, M.A., Schlacher, T.A., 1998. Accumulation, contamination, and seasonal variability of trace metals in the coastal zone patterns in a seagrass meadow from the Mediterranean. Marine Biology 131, 401-410.

Schropp, S.J., Lewis, F.G., Windom, H.L., Ryan, J.D., Calder, F.D., Burney, L.C., 1990. Interpretation of metal concentrations in estuarine sediments of Florida using aluminum as a reference sediment. Estuaries 13, 227-235.

Short, F.T., Wyllie-Echeverria, S., 1996. Natural and human-induced disturbances of seagrasses. Environmental Conservation 23, 17-27.

Tomasko, D.A., Hall, M.O., 1999. Productivity and biomass of the seagrass Thalassia testudinum along a gradient of freshwater influence in Charlotte Harbor, Florida. Estuaries 22, 592-602.

Tiller, K.G., Merry, R.H., Zarcinas, B.A., Ward, T.J., 1989. Regional geochemistry of metal-contaminated surficial sediment and seagrasses in Upper Spencer Gulf, South Australia. Estuarine, Coastal and Shelf Science 28, $473-493$
U.S. Environmental Protection Agency, 1990. The environmental and economic status of the Gulf of Mexico. Symposia Proceedings, Gulf of Mexico Program, Stennis, MS.

U.S. Environmental Protection Agency, 1992. Status and Trends of Emergent and Submerged Vegetated Habitats, Gulf of Mexico, U.S.A. Office of Water, Washington, DC. EPA-800-R92-003.

U.S. Environmental Protection Agency, 1994. Toxic substances and pesticides. Action Agenda for the Gulf of Mexico. EPA 800-B-94-005, Office of Water. Stennis Space Center, MS.

U.S. Environmental Protection Agency, 1997. Methods for Determination of Chemical Substances in Marine and Estuarine Environmental Matrices, second ed. U.S. EPA, Washington, DC. EPA/600/R-97/072.

U.S. Geological Survey. Draft: Gulf of Mexico Seagrass Status and Trends, U.S.G.S. Scientific Investigations Report. National Wetlands Center, Lafayette, LA, in press.

Virnstein, R.W., 1987. Seagrass-associated invertebrate communities of the southeastern U.S.A.: a review. In: Durako, M., Phillips, R.C., Lewis, R.R. (Eds.), Proceedings of the Symposium on Subtropical-Tropical Seagrasses of the Southeastern United States. Florida Marine Research Publications. Florida Department of Natural Resources, Tallahassee, FL.

Warnau, M., Ledent, G., Temara, A., Bouquegneau, J.M., Jangoux, M., Dubois, P., 1995. Heavy metals in Posidonia oceanica and Paracentrotus lividus from seagrass beds of the northwestern Mediterranean. Science of the Total Environment 171, 95-99.

Ward, T.W., Correll, R.L., Anderson, R.B., 1986. Distribution of cadmium, lead and zinc among the marine sediments, seagrasses and fauna and the selection of sentinel accumulators near a lead smelter in South Australia. Australian Journal of Marine and Freshwater Research, 567-586.

Williams, T.P., Bubb, J.M., Lester, J.N., 1994. Metal accumulation within salt marsh environment: a review. Marine Pollution Bulletin 28, 277-290.

Zieman, J.C., Fourqurean, J.W., Frankovich, T.A., 1999. Seagrass die-off in Florida Bay: long-term trends in abundance and growth of turtle grass, Thalassia testudinum. Estuaries 22, 460-470. 